\title{
UNCOVERING "HIDDEN MESSAGES" IN HILLARY CLINTON'S CONCESSION SPEECH POST-PRESIDENTIAL DEFEAT: A CRITICAL DISCOURSE ANALYSIS
}

\author{
Dery Rovino* \\ English Education Study Program, Sekolah Tinggi Keguruan dan IImu Pendidikan Media Nusantara Citra \\ Received on 3 April 2019 / Approved on 12 April 2019
}

\begin{abstract}
Due to a narrative that speeches may assist with understanding gender identity indexical(s) in politics, this study aims to discover such meanings underneath the text production of Hillary Clinton's concession speech post-defeat in the latest US presidential election. Through Critical Discourse Analysis - Text as A Critical Object (CDA - TACO), it seems evident in Hillary Clinton's speech that there are patriotic lexical choices, parallelism, alliteration, anthropomorphization, and repetition for emphasis, personal pronoun "I" and "my", suggesting a certain degree of assertiveness, which are generally specific to male politicians (Reyes, 2015). There is a marked use of collective pronoun "we", "our", connoting a level of intimacy between the speaker and audience, interestingly however, evidenced not only on Clinton's speech but male politicians as wel, thus rendering it gender-neutral. Evidences of backgrounding, thus distancing self, when the politician utters disappointments are noticeable. Findings partially prove that gender-driven lexical choice by Hillary Clinton noticeably conforms to those of male orators in politics, although most of her expressions suggest commonality of political speeches. Limitations of the study are put forth.
\end{abstract}

Keywords: gender; politics; identity indexical(s); CDA

\section{ABSTRAK}

Terdapat wacana yang menyatakan bahwa pidato terdapat indeksikal identitas gender dalam politik, penelitian ini bertujuan untuk menemukan makna tersebut dalam pidato konsesi Hillary Clinton pascakekalahan dalam pemilihan presiden AS terakhir. Dengan Analisis Diskursus Kritis - Teks sebagai Objek Kritis (CDA - TACO), tampak jelas dalam pidato Hillary Clinton bahwa terdapat pilihan leksikal patriotik, paralelisme, aliterasi, antropomorfisasi, dan pengulangan untuk penekanan, kata ganti pribadi "I" dan "saya", menunjukkan tingkat ketegasan tertentu, yang umumnya digunakan politisi pria (Reyes, 2015). Terdapat penggunaan yang jelas dari kata ganti kolektif "kami", "milik kami" yang menyiratkan tingkat keintiman antara pembicara dan audiens, tetapi menarikna, penggunaan kata ganti ini tidak hanya pada pidato Clinton tetapi juga para politisi pria, sehingga menjadikannya gender-netral. Elemen-elemen backgrounding, sehingga menyiratkan penjauhan diri, ketika politisi mengungkapkan kekecewaan cukup terlihat. Temuan ini membuktikan sebagian bahwa pilihan leksikal yang didasari oleh gender pada pidato Hillary Clinton sesuai dengan orator laki-laki dalam politik, meskipun sebagian besar ekspresinya menunjukkan kesamaan pidato politik. Keterbatasan penelitian dikemukakan.

Kata Kunci: gender; politik; indeksikal identitas; CDA

\section{INTRODUCTION}

Women involvement in politics has been hotly debated in the past few decades. It is interesting that Koyuncu et.al (2016) concludes women's role in Turkish parliament being limited to representative roles. This could mean that women's presence in such political context may not reflect a substantive decision-making power, thus they merely

*Author(s) Correspondence:

E-mail: dery.rovino@stkipmnc.ac.id 
become "a token" for a simplistic symbolic presence. Additionally, among other findings, a study in Ontario, Canada found that women have been underrepresented in twenty-two cities during their respective municipal elections in 2014 (Spicer, McGregor, \& Alcantara, 2017) which further proves that female political engagement is less favored in those districts. On the other hand, other study showed that women's role in formal political candidacy is closely related to general women's positive attitude in politics although female's direct influence towards policy making still demands some answers (Karp \& Banducci, 2008).

From the above findings, though rather mixed, it can be concluded in the interim that women seem to inherit a number of political challenges. This is compelling due to the fact that a female presidential candidate, Hillary Clinton, still competed for the Oval Office position in the last USA presidential election against a male counterpart. Hillary's decision to run for president is then considered a breakthrough in the American presidential election considering the fact that, as Rosen (2017) puts it, generally politics is almost male-driven thus making females on the disadvantage side.

Although the USA presidential election has passed and the winning candidate eventually a male, Hillary Clinton's run still remains intriguing to investigate. While her candidacy can be investigated through a battery of disciplines, this study limits itself to only probing around Mrs. Clinton's exit speech post-presidential defeat by implementing a linguistic analysis. This is due to a narrative that linguistics may assist with understanding a discourse through its text. Fairclough (1995) puts forward a Gramscian term of "hegemony" as an ideological underpinning to a discourse, including politics. Further, Paechter (2018) claims that hegemony of masculinity narrative emphasizes the subordination of femininity. Therefore, it would be natural for those belonging to the feminine side to express subversion towards such masculine dominance. Also, perhaps it may not be uncommon for the politically less favored gender to adapt to the dominant gender in a form of linguistic fetishism through an act of "mimicking" the language devised by the favored gender (Niño Murcia, 2003). However, at this point, we have minimal assurance whether there have been attempts for Hillary Clinton to embody maleinherited linguistic choices in attempts to make herself relatable to the already masculineendowed political world. Therefore, the following research question is formulated:

Are there any gender-driven linguistic choices evident from the Hillary Clinton's postpresidential defeat?

In order to answer the research question above, a tool of analysis namely Critical Discourse Analysis (CDA) is devised. Fairclough (1995) suggests that co-textual analyses in order to investigate meaning may not be sufficient, especially considering the context role in the meaning interpretation. Therefore, Fairclough puts forward CDA that allows texts to be interpreted from their interrelationships between co-text and context. Further discussion for CDA will be further laid out in the following chapter.

This study may benefit several aspects in the orbit of this text. On the textual level, this study may assist with adding a few layers of meanings through CDA interpretation. The result of this study too may help bringing insights to students generally and student researchers specifically in relation to providing access for textual analysis beyond its co-text relationships. This study may further assist with expanding possibilities of research practices in language and text analysis which takes into account the overarching ideology that may persist in the text production itself (Wallace, 2003). O'Regan (2006) further believes that Critical Discourse study may be applicable in the classroom context in that it assist with engaging students and their analytical skills in evaluating reading passages, which in turn may help develop students' critical thinking skills.

\footnotetext{
*Author(s) Correspondence:

E-mail: dery.rovino@stkipmnc.ac.id
} 


\section{LITERATURE REVIEW}

\section{Identity Indexical(s) and the Narrative of Gender in Politics}

One notable theorist in gender studies, Judith Butler (2006) proposes varying dimensions at work in regards to gender studies: "anatomical sex, gender identity, and gender performance" (p. 187). Butler took the example of "drag queens" or drag performers - known to be men - in that they portray an exaggeration of female representation in their shows. What is interesting is that these drag performers live their lives as a part of the male group. This, then, may prove that one may maintain their sex anatomy and gender identity while portraying either gender representation through varying modes of symbols, including language.

However, Butler admits that humans are tied to display a particular (gender) performance that aligns with "cultural norms" (Rovino, 2017). It is only logical that the narrative of culture and gender nowadays is associated to the stereotype of gender. Due to the findings that politics are culturally maledominated (Koyuncu L. \& Sumbas, 2016), it would then raise the needs to look closely into how male politicians, especially in the USA, utilize linguistic choices. Reyes (2015) provide useful analysis on the linguistic choices of males in American politics. The scholar analyzed a battery of speech manuscripts of notable male American politicians such as Joe Biden, George W. Bush, and Barrack Obama.

Reyes (2015) describes the alternation between the pronoun uses of "I" and "you" by male politicians establishes a more contextual relationship between interlocutors, thus may reflect certain degree of intimacy between the speaker and audience. Inclusive personal pronoun "we" is regularly used to emulate varying ways of establishing rapport and intimate relationship with the audience. According to Reyes, there may be attempts of including the audience into political arguments put forth in these speeches. It is as if the audience assists with the decision-making process of whatever being presented by the politicians. Lempert \& Silverstein (2012), in Reyes (2015) best put a notion that "political communication" needs an attempt of "recognizing" thus "co-membership" between the speaker and audience can be enacted. These male politicians then embed a level socio-cultural nuance in their speeches in that the term "kitchen table" is frequently evidenced. This, according to Reyes (2015), denotes a place where most American families have family discussion in, thereby connotes yet another attempt to emphasize familiarity, or "relatable", nature of the speech. Such attempts to build rapport with the audience and "relate-ability" are what Reyes regards as "identity indexicals".

On another end, Reyes (2015) also provides an analysis of Sarah Palin. The scholar claims that "identity indexicals" are evident in Palin's speech as well. There is also attempt of inclusion between the speaker, Palin, and the audience when she refers herself as a part of "Hockey moms across the nation" and "middle class of America" where she and her husband belong to. However, there have been attempts by Palin to empathize on the natural damages that might take place in her state of Alaska through her line, as written in Reyes (2015): "You know what I had to do in the state of Alaska? I had to take on those oil companies and tell them, "No," you know, any of the greed there that has been kind of instrumental, I guess, in their mode of operation, that wasn't going to happen in my state". This chain of expression indeed comes from an empathetic place of Palin towards the state she leads. Empathetic lexical choices, thus make them emotive, are closely related to feminine-driven language. However, if evaluated closely, the frequent uses of personal pronoun "I" and possessive personal pronoun "my state" may suggest an authoritative nature evident and regular to be used in the male group of politicians. This, therefore, may suggest an association between gender, language, and identity indexicals between female politicians and their male counterpart. Palin's authoritative language choice that is common to male politician then may suggest a level of subscription towards

\footnotetext{
*Author(s) Correspondence:

E-mail: dery.rovino@stkipmnc.ac.id
} 
the dominating gender in the political sphere. This is perhaps what Pierre Bourdieu labels as "linguistic fetishism" (Bourdieu, 1977; Sparrow \& Hutchinson, 2013) where language choices devised by the speakers in accordance to the overarching ideology that persists. Therefore, from the discussion brought up by Reyes (2015), there is possibility that Palin's lexical choices are indexing that of maledriven choices of lexeme at work.

\section{Critical Discourse Analysis - Text as A Critical Object (CDA - TACO)}

This paper provides a critical discourse analysis of a speech by Hillary Clinton upon her presidential defeat over Donald Trump in the 2016 USA election. The object of analysis was chosen in order to explore a few shades of the ideological underpinnings of a particular text (Wallace, 2003), to provide an insight of how a certain text emulates focal principles of CDA, and to explain how it exudes domination and power to which entails social inequality (Van Dijk, 2008). The interdisciplinary value of spoken discourse (Cameron, 2001) led this paper to attempt to uncover linguistics and nonlinguistic constituents (Gumperz, 1992; Lanham, 1991; Montgomery, 1999) and how they may possibly shed a light of interpretation towards its pragmatic meanings (Cameron, 2001).

A number of notable linguists over decades ago had developed frameworks in order to uncover relations between texts and contexts. Halliday $(1973 ; 1994)$ provides the concept of register composed by field, tenor, and mode (Martin, 2010). In another work, Halliday came up with another set of analysis tool namely Systemic Functional Linguistics (SFL) in which the scholar aims to uncover the textual meanings by analyzing three agencies involved: actor; circumstance; and process. SFL regards language as a resource for making meaning and not limited to rules (Martin, 2010), which in turn allows minimal tools of analysis for texts whose meaning could be negotiated and extended beyond the realm of the texts themselves.

\footnotetext{
*Author(s) Correspondence:

E-mail: dery.rovino@stkipmnc.ac.id
}

In light of discourse and its relations with power, Foucault (1977) theorizes:
"There is a system of power which blocks, prohibits, and invalidates this discourse and this knowledge, a power not only found in the manifest authority of censorship, but one that profoundly and subtly penetrates an entire social network. (Foucault, 1977)"

The above excerpt may arguably imply that Foucault consider power as an invisible yet powerful influence where it governs the layered aspects of social, discoursal, and textual. Taken further, Fairclough's power relations provides further approach in that he essentially suggests internal influences to persist within the social institution, social formation, and social action (Fairclough, 1995). In the cases of political speeches, its production usually is not free of such influence. Therefore, it can be argued that SFL might be less favorable as a tool of analysis.

John O'Regan's (2006) Text as Critical Object (TACO) model, was chosen as the apparatus of analysis for Hillary's concession speech is due to the following considerations. Firstly, Wallace (2003) suggests that "critical language analysis did not disappear, but continued to evolve in a number of ways', in which consequently Wallace's claim may further suggest that TACO model may become one of further extension of the tools of Critical Discourse Analysis prior. Furthermore, apart from having more extensive version of Fairclough's framework of CDA, TACO is more accessible for students with limited linguistic background who wish to undergo critical discourse analysis, as it is claimed that TACO frameworks is constructed in a way to 'demystify' the CDA procedures (O'Regan, 2006). Furthermore, O'Regan's (2006) argues that TACO enables "immanent" reading to a written text by allowing the analysis to intertwine with the wider sociocultural and ideological notions available.

Moreover, one arguably cannot discuss CDA without addressing the roles of domination which Fairclough (1989) and 
Chouliaraki \& Fairclough (1999), in Wallace (2003), posit in that domination does not necessarily entail "tyrannical" forces. Instead, Gramsci (1971) theorized that domination exercised by the ones with power through hegemony: they must abide by 'a balance of force or persuasion' (Wallace, 2003). Ultimately, Fairclough's dimensional view of discourse: description; interpretation; and explanation (O'Regan, 2006) seem to agree with the Gramscians in a way that there are relationships between textual and social components of a discourse.

\section{A Closer Look to CDA TACO with Gender Discourse}

Norman Fairclough's Critical

Discourse Analysis (Fairclough, 1995) becomes relevant to this text analysis where he acknowledges "the three-dimensional view", textual, discoursal, and social layer, and claims their relationship(s) that can be found within. However, O'Regan's (2006) Text as a Critical Object (TACO) appears to provide an extensive version from that of Fairclough's due to its "deconstructive interpretation" stage to see whether elements of each layer appear "to contradict or undermine the preferred reading" (O'Regan, 2006, p. 19). O'Regan claims that TACO can serve to investigate the ideological patterns of the text because TACO is "[d]erived from critical social theory [...]" (p. 41). In relation to this study, therefore, devising TACO seems appropriate due to the "gender ideology talk" seems to closely relate to aspects of social theory.

In the gender discourse, Hodge \& Kress (1988) argue that each of the world's communities essentially complies with the biological endowments of human to generally separate men and women. This type of biological "segregation", therefore, is responsible for the "innumerable cultural rules that specify and control behavior along gender lines" (Hodge \& Kress, 1988, p. 97). Such ideology, in turn, offers somewhat of a closure into the gender understanding, perpetuated by a lot of the world's society that is imposed to diverse individuals who do not necessarily fit into the pre-shaped gender mold. For that reason, O'Regan's TACO supplies a deconstructive tool to challenge the preconditioned cultural norms. The followings explain TACO in details:

\begin{tabular}{|c|c|c|}
\hline \multicolumn{3}{|c|}{$\begin{array}{l}\text { Table 1: CDA Text as a Critical Object (O'Regan, } \\
\text { 2006) }\end{array}$} \\
\hline Stages & Definition & $\begin{array}{l}\text { Guiding } \\
\text { Questions }\end{array}$ \\
\hline $\begin{array}{l}\text { Descriptive } \\
\text { Interpretation }\end{array}$ & $\begin{array}{l}\text { How the text } \\
\text { generally wishes } \\
\text { to be read/ } \\
\text { preferred } \\
\text { reading; who } \\
\text { the ideal } \\
\text { reader(s) are }\end{array}$ & $\begin{array}{l}\text { Frame of the } \\
\text { text? Macro } \\
\text { genre? Micro } \\
\text { genre? Topic } \\
\text { presentation? } \\
\text { Preferred reading } \\
\text { \& preferred } \\
\text { reader(s)? }\end{array}$ \\
\hline $\begin{array}{l}\text { Representative } \\
\text { Interpretation }\end{array}$ & $\begin{array}{l}\text { What social } \\
\text { values can be } \\
\text { attached to the } \\
\text { discourse } \\
\text { features of the } \\
\text { text (image/ } \\
\text { vocabulary/ } \\
\text { grammar/ } \\
\text { genre)? }\end{array}$ & $\begin{array}{l}\text { Discourse } \\
\text { features: Image? } \\
\text { Vocabulary? } \\
\text { Grammar uses? } \\
\text { mix of genre? }\end{array}$ \\
\hline $\begin{array}{l}\text { Social } \\
\text { Interpretation }\end{array}$ & $\begin{array}{l}\text { The social } \\
\text { context(s) which } \\
\text { the text seems to } \\
\text { be a part of (e.g. } \\
\text { gender, race, } \\
\text { economy, } \\
\text { business, } \\
\text { politics, family, } \\
\text { class, income, } \\
\text { age, sex, } \\
\text { property, } \\
\text { geography, } \\
\text { etc.)? }\end{array}$ & $\begin{array}{l}\text { What social } \\
\text { frameworks is } \\
\text { the text a part of? } \\
\text { What typical } \\
\text { kinds of social } \\
\text { knowledge do } \\
\text { these } \\
\text { frameworks } \\
\text { suggest? }\end{array}$ \\
\hline $\begin{array}{l}\text { Deconstructive } \\
\text { Interpretation }\end{array}$ & $\begin{array}{l}\text { Aspects of the } \\
\text { descriptive, } \\
\text { representative, } \\
\text { and social } \\
\text { dimensions of } \\
\text { the text which } \\
\text { appear to } \\
\text { contradict or } \\
\text { undermine the } \\
\text { preferred } \\
\text { reading. }\end{array}$ & $\begin{array}{l}\text { Does any aspect } \\
\text { of the text's } \\
\text { internal structure } \\
\text { appear to } \\
\text { contradict or } \\
\text { undermine the } \\
\text { text's preferred } \\
\text { reading } \\
\text { Immanent } \\
\text { critique/ internal } \\
\text { "texturing" that } \\
\text { opposes? }\end{array}$ \\
\hline
\end{tabular}

'Descriptive Interpretation' allows critical discourse analysts to evaluate how the text superficially wishes to be read (preferred reading). Text elements i.e. layout, macromicro genre, topic presentation, along with preferred reading and preferred audience are

\footnotetext{
*Author(s) Correspondence:

E-mail: dery.rovino@stkipmnc.ac.id
} 
taken into consideration. As the next stage, 'Representative interpretation' allows an evaluation towards social values that might be attached to the discourse features of the text. Elements such as image, vocabulary, grammar, and genre are considered as the features where social values might be embedded to. 'Social Interpretation' assists with evaluating the interpretations in the descriptive and representative stage through interrelating them with the "social knowledge" that might be encoded into the text. Lastly, 'Deconstructive Interpretation' allows the analysts to revisit their previous interpretation stages to see if the interpretative elements support or contradict with each other.

Fairclough claims that people, as a group of "social subject", have their linguistic choices embedded with "ideational meaning" and "social relations underlying interactional practices" (p.24). Therefore, utilization of Discourse Analysis might not be applicable to my research aims. Discourse Analysis has been criticized for its decontextualized nature, "[...] (noncritical discourse analysis) lack[s] of concern with explanation - with how discursive practices are socially shaped, or their social effects" (Fairclough, 1995, p. 24). Therefore, the use of CDA in this study will allow myself to unpack social values, including gender identity indexicals, that underlie Hillary Clinton's political speech.

\section{ANALYSIS AND DISCUSSION}

\section{Descriptive Interpretation Frame of Text}

In the speech transcript obtained from the internet ("Hillary Clinton's concession speech (full text)," 2016) cross-referenced with a video retrieved from a video hosting website ("Hillary Clinton FULL Concession Speech | Election 2016 [Youtube]," 2016), Hillary Clinton's speech visually starts at the minute $6: 11$, concludes at $18: 55$, lasts for approximately 12 minutes. The speech is a part of a larger ensemble that includes Tim Kaine's opening speech and is closed by a brief voice- over commentary. This is to also state that only Hillary's speech that is analyzed.

General intention of the speech seems to Searlian's expressives (Binton, 2000; Montgomery, 1999) in that she was to thank all supports given to her pre-, during and postpresidential campaign. Further, having realized that the speech transcript found in the internet does not document a selection of noteworthy components, significant alteration on the transcript is applied to pinpoint audio-visual communicative signals (Gumperz, 1992; Martin, 2010). To this analysis, it is argued that cues other than those of verbal cues (laughter, cheers, and applauses) are deemed valuable to observe audience's validation (Montgomery, 1999). In order to facilitate the alterations, the speech is further broken down into 129 lines according to the utterances' final cues, be it pauses or silences (Gumperz, 1992). From the audience point of view, time elapsed for laughter, cheers and applause was approximately 4 minutes, equivalent to onethird of the overall speech. Further, it is interesting that 11 throat clearings and 13 mouth clicks are evident during the speech. More explanations on those non-verbal cues is to be explained further in the analysis.

\section{Genre}

While the macro genre of Hillary's speech is known to be political statement, there is a few micro genres implemented in the speech. Due to the fact that Hillary was delivering a political statement mainly in front of her supporters with whom she embarked her 2016 presidential campaign, evidences of recount genres are mostly utilized because she does not need to report or build rapport with the viewers (Martin, 2010).

\section{Topic Presentation}

While formal mode of delivery is evident throughout the speech, a few hints of informal lexis are evident:

15. //Very rowdy group//;

21. Audience: //We love you//

22. //and I love you all / too.//

*Author(s) Correspondence:

E-mail: dery.rovino@stkipmnc.ac.id 
Also, lexical choices that suggest patriotism to the USA are evident as phrases and clauses such as: "our country"; "country we love"; "building an America"; "our nation"; and "strength in our convictions and love for this nation" are employed. Hillary further attempts to be "relatable" to her economically middleto low-class supporters when she thanks for donations given to her campaign by saying "To everyone who sent in contributions as small as \$5 and kept us going (line 80)". There are Hillary's attempts to be humorous in order to radiate friendliness, through highlighting her baby's presence (now a grown up man who happens to be present on stage with her) during her past political works. This friendly move is successful as it is followed by the audience's laughter:

69. You crisscrossed this country / on our behalf and lifted me up when I needed it most / even four-month-old Aidan who traveled with his mom (mouth click). // 70.Audience laughter

Humor, which is believed to enforce positive validation (proven by the audience's laughter upon her attempt to be humorous) and to tone down the degree of formality, is also added when she addresses her supporters that secretly support her candidacy.

75. And to the millions of volunteers / community leaders / activists and union organizers / who knocked on doors / talked to neighbors / posted on Facebook / even in secret / private... Facebook sites//

76. Audience laughter

The above interpretation suggests that although the speech is presented mostly in the formal and patriotic style, there are a few informal values such as attempts to be humorous and friendly.

\section{Preferred Reading and Preferred Audience}

There are 16 instances of "thank you" throughout the text which may arguably suggest that the preferred reading of the
Hillary's speech is essentially to thank and show gratitude towards the supports given to her during the presidential campaign. Furthermore, line 23-24 and especially assertion given off in line 42: "//Donald Trump is going to be our president / we owe $\underline{\text { him }}$ an open mind and the chance to lead.//" implies that the preferred audience can be polarized for both her and her opponent's political supporters.:

23./Um (0.1) last night, I I
congratulated Donald Trump and
offered to work with him on behalf of
our country.//
24.//I hope that he will be a successful
president for all / Americans.//

\section{REPRESENTATIVE INTERPRETATION Image}

It can be arguably concluded that most political statements are scripted, which means that Hillary's speech is no different. Nevertheless, Hillary delivers the speech in a way that is firm and sufficiently eloquent. She strategically gazes at the audience that are in different section of the ballroom. She enunciates her pronunciation, meaning that there are no contractions evident in the speech. She paces herself well thus makes her speech sufficiently audible (apart from being facilitated with voice-amplifying equipment). Word stresses are well-thought of, especially when she exhibits a virtue by wishing Donald Trump a success in leading the country, "//I hope that he will be a successful president for all Americans.//" (line 24). From the already mentioned ways of the image presentation, she projects grace and wisdom. Although authoritativeness seem to be less evident, perhaps due to the fact that she has just been defeated in an election, she employs a repetition method in a powerful lexis (the word "fighting") to drive audience's positive responses:

87.//This loss hurts / but please (0.1) never stop believing that fighting for what's right is worth it.// (repetition)

\footnotetext{
*Author(s) Correspondence:

E-mail: dery.rovino@stkipmnc.ac.id
} 
88. cheers and applause (0.6)

89. Clears throat

90. cheers and applause (0.14)

$91 . / /$ It is / it is worth it.// (repetition)

92. cheers and applause (0.4)

93. /And sol

94. cheers and applause (0.2)

95.We need / we need you to keep up

these fights now and for the rest of your

lives.//

96. //And to all the women/ [...] / I want you to know that nothing has made me prouder / than to be your champion.//

As mentioned previously, what the audience projects following an expressed utterance by a public speaker may be taken as a form of validation (Montgomery, 1999). Concerning Hillary's speech, therefore, the longer time elapsed in the audience's laughter, cheers, and applauses (26 seconds) is relevant with how strategic she places powerful lexis (line 87-95).

Although the overall theme of Hillary's speech is about thanking supporters, a few mouth clicking instances may imply Hillary's disappointments, as they are located either in the initial, medial or final of a few clauses that are thematized as the disappointment.

\section{5.(mouth click) //I know how disappointed you feel because / I feel it too (nod) / and so do tens of millions of Americans who invested their hopes and dreams in this effort// \\ 36.//This is painful / (mouth click) / and $\underline{\text { it }}$ will be for a long time / \\ 39.//We have seen that our nation is more deeply divided than we thought (mouth click).//}

The compelling part of this particular instance is that Hillary is being sufficiently cautious in expressing her disappointment by either putting her supporters in the highlight, the use of demonstrative determiner "this" (Binton, 2000), the use of subject pronoun "it" and "we", and essentially putting herself in the low-light, while she could have expressed her disappointment by putting herself as the main subject. "I am disappointed by...".

\section{Vocabulary}

Although semantically a few utterances may suggest informality, the overall vocabulary choices are crafted in a way that is proper, proud, and patriotic. Further, a simplistic concordance software AdTat (Watling, Cargill, Green, Adams, \& Hall, 2007), pinpoints phrases that suggest patriotism and pride such as "I am an American", "[...] many Americans", "the American dream", "millions of Americans".

Hillary points out a number of achievements during her political career and the campaign, shows gratitude to the supports of her campaign staff and the voters, and even provides advice for those who wish to pursue political career. Having been discussed in the "image" subsection, clauses suggesting disappointments are noticeable. However, these cues were quickly mitigated by highlight-lowlight method and the use of resilient and patriotic clauses in order to not sound vulnerable. Instead, an ideational meaning is radiated through various lexical choices ("fighting", "pride and gratitude", "your champion") that may be built under the theme of resilience. The theme is further supported by the use of modal verb "must" in this particular utterance: "//And if you do / then / we must accept this result and then look to the future.//" to indicate obligation (Gee, 1999) that is directed towards Hillary's political supporters.

Furthermore, significant amount of characterized linguistic components are devised in the speech. To start, Hillary utilized a number of alliterations, e.g. "successes...setbacks" (line 83), especially on the intentional use of gerund/ -ing, plural -s/ es, and final sound /Or/, parallelisms, and repetitions to impose greater positive effects on her speech:

25.//This is not the outcome we wanted I or we worked so hard for / and I'm sorry I that we did not win this election for the values we share / and the vision we hold

*Author(s) Correspondence:

E-mail: dery.rovino@stkipmnc.ac.id 
for our country.// (parallelism \& alliterations)

51.//So let's do all we can to keep advancing the causes and values we all hold dear / making our economy work for everyone not just those at the top / protecting our country and protecting our planet / and breaking down all the barriers that hold any American back from achieving their dreams // (alliterations \& parallelisms)

54. //S -- so now / our responsibility as citizens is to keep doing our part / to build that / better / stronger / fairer America we seek / and I know you will.// (alliteration)

71. // I will always be grateful / to the creative / talented / dedicated men and women at our headquarters in Brooklyn and across our country// (alliteration)

Further, anthropomorphization, in a nutshell, is when animals are given human-like qualities. One may think of movies, e.g. Lion King, due to the fact that these animals talk and converse in the film. However, more experts contributed to more definitions to anthropomorphization, to which it may occur in a particular discourse to the following possible conditions: (a) non-human entities (mythical creatures, gods, animals or nonliving things) are given human qualities, (b) assimilation between human-like and animallike qualities in one entity, and (c) human borrows non-human persona (Ailes, 1991; Han, 2009; Hyman, 2013; Sabanpan-Yu, 2009). Concerning the speech, moreover, Hillary uses a number of instances of anthropomorphization techniques. Similar to other vocabulary-based moves (e.g. parallelism, repetitions, and alliterations), Hillary yet again attempts to inflict the greater enthusiasm from the audience through her breadth of lexical choices. See the following extracts:

\footnotetext{
*Author(s) Correspondence:

E-mail: dery.rovino@stkipmnc.ac.id
}

\section{8. [...] this vast/ diverse/ creative/ unruly/ energized campaign//}

38.//it was about the country we love and about building an America that's hopeful / inclusive and big-hearted// 39.//We have seen that our nation is more deeply divided than we thought $[\ldots] / /$

43.//Our constitutional democracy enshrines the peaceful transfer of power I (mouth click) (head shake) and we don't just respect that / we cherish it//

44.//It (constitutional democracy) also enshrines other things / (0.1) / the rule of law / the principle that we are all equal in rights and dignity / freedom of worship and expression / we respect and cherish these values too /

50. // and / and let me add / our constitutional democracy demands our participation / not just every four years / but all the time (mouth click) /

\section{1. //To Barack and Michelle Obama / our country owes you an enormous debt of gratitude.}

\section{7. //we thank you for your gracefull determined leadership /}

Furthermore, there are other synonymic words to the word "to invest" (e.g. "to put") in line 35, hence the sentence may have sounded like, "... and so do tens of millions of Americans who put their hopes and dreams in this effort." However, Hillary's logic to use the word "to invest" may have been twofold: (a) the more positive energy driven from the audience; and (b) the verb "to invest" means to purchase something with a capital - usually monetary - with expectations of gaining future profits (Oxford Learner's Dictionaries, 2016), and the fact that "tens of millions of American" \& "hopes and dreams" are juxtaposed as the unanimous subject and the object respectively, it may perhaps be 
concluded that a vast number of Americans are in an unfortunate loss for "buying" Hillary's Presidential candidacy with their hopes and dream due to their candidate's defeat. See the following extract:

35. (mouth click) //I know how disappointed you feel because / I feel it too (nod) / and so do tens of millions of Americans who invested their hopes and dreams in this effort//

Hillary uses, yet again, another metaphoric move when she thanks her family members for their supports of her political endeavors. Though the followings may not be significant to the whole theme of the speech, it is noteworthy to discover how Hillary is adherent to the uses of such figurative languages in the speech:

\section{You crisscrossed this country / on our behalf and lifted me up when I needed it most}

\section{You poured your hearts into this campaign / for some of you who are veterans, it was a campaign after you had done other campaigns / some of you / it was your first campaign. // I want each of you to know that you were the best campaign anybody could have ever expected or wanted.}

\section{Grammar}

While the frequently used tenses is the present form in order to articulate facts, pastforms and present participles become the two of the frequently occurring tenses. This is possibly due to the fact that Hillary is being reminiscent of what she and her political army have gone through during the campaign process. Concerning the use of subject pronouns, AdTat (Watling et al., 2007) is used to summarize the frequency of the following pronouns as follow: I (24); my (6); you (30); your (8); we (26); our (24); they (0); their (3). Looking at the use of pronouns, where she extensively uses "you" \& "your" and "we" \& "our", it may be concluded that Hillary attempts to avoid making herself the theme of the clause (explained by less uses of subject pronoun "I" and "my"). This claim is strengthened by the use of "we" and "our" in the speech that suggests shared responsibilities between parties, and not only Hillary's (Cameron, 2001).

Gee (1999) points out that the use of modal verbs in both written and spoken utterances may entail to the following functions: possibility, probability, obligation, intention, future prediction, ability, etc. While there is only one modal verb used to identify obligation, "you know, I believe we are stronger together and we will go forward together/ and you should never / ever regret fighting for that./" (199-120), there is a significant number of modal verb "will" to indicate a few acts (Binton, 2000; Gee, 1999; Montgomery, 1999) to serve the following objectives:

\section{Prediction:}

36. //This is painful / (mouth click) / and it will be for a long time /

54. //S -- so now / our responsibility as citizens is to keep doing our part / to build that / better / stronger / fairer America we seek / and I know you will.// 104. // I / I know / I know we have still not shattered that highest and hardest glass ceiling/ but some day/ someone will// and hopefully sooner than we might think right now.//

\section{Intention:}

40. //But I still believe in Americal and I always will.//

119. /you know, I believe we are stronger together and we will go forward together./

In line 36, it is suggested that Hillary projects disappointments, though by using the determiner "this". This may lead to a conclusion that Hillary essentially expresses disappointments, to which it is rather challenging to recover from the defeat. However, disappointments are quickly mitigated by expressing her positive

\footnotetext{
*Author(s) Correspondence:

E-mail: dery.rovino@stkipmnc.ac.id
} 
standpoint and hopes for America (line 40, 104, and 119). Those moves may have accounted for contributing to the whole preferred reading of the speech.

\section{Mix of Genre Evidences}

As described in 2.1.2., political speech as the macro genre is evident due to the fact that this is a speech delivered by Hillary Clinton, a political figure, following her presidential election defeat over Donald Trump in 2016. Furthermore, the mix of micro genre is evident as well. While it has already been clear that non-verbal cues (laughter, cheers, and applauses) constitute to communicative signals in order to check with the spectators' feelings towards the public speaker (Montgomery, 1999), in the beginning of the speech there is an exchange of communicative signals (Gumperz, 1992) in a form of a conversationworth group of utterance. This happens where Hillary reactively reciprocates to her audience's impulsive shouts:

\section{Audience: //We love you// \\ 22. Hillary: //and I love you all / too.//}

Notice that in terms of the illocution, the audience employs representatives (Binton, 2000; Hatch, 1992) as they state liking/ admiration towards a political idol by enthusiastically shouts "we love you". And Hillary, stimulated by the audience, is prompted to respond to the affection by stating that she loves them too. Such impulsive unscripted communicative component may entail sincerity value and the emotional bond being strengthened, as both parties express how they feel about each other (Montgomery, 1999).

The background story between Hillary and Trump has already been established hence there is no need for building up assumption when Hillary expresses her interest in joining forces in leading the USA, "/Um (0.1) last night, I / congratulated Donald Trump and offered to work with him on behalf of our country.//" (line 23). Similar recount value is evident when she elaborates the past campaign, "// We've spent a year and a half / (mouth click) / bringing together millions of people from / every corner of our country / to say with one voice that we believe / that the American dream is big enough for everyone / for people of all races and religions / for men and women / for immigrants/ for LGBT people and people with disabilities / for everyone.//" (line 52). She also recounts her family's contributions in her past political endeavors, including the past campaign when she says, "You crisscrossed this country / on our behalf and lifted me up when I needed it most / even four-month-old Aidan who traveled with his mom (mouth click).//. To sum up, there is a mix of genres exemplified in the speech, to which they serve semantic values to the discourse.

\section{SOCIAL INTERPRETATION \\ Social Framework Constituents}

Social framework refers to the relationship between the text with the bigger, possibly the biggest, schemas to where the text may abide by/ conform to (O'Regan, 2006). The constituents of social framework belonging to this particular speech is arguably twofold: politics and gender. The bigger social framework of this speech is politics, where it leans on the whole genre of political speech. Hillary uses lexis such as "constitutional democracy (line 43 \& 50)", "making our economy work..." (line 51), brings up her political track records "//I've had successes and I've had setbacks.//" (line 83), thanks her family, political campaign supporters and also President Barrack Obama and First Lady Michelle Obama "//To Barack and Michelle Obama / our country owes you an enormous debt of gratitude.// We / //we thank you for your graceful/ determined leadership / that has meant so much to so many Americans and people across the world//" (line 61-67).

Furthermore, this may not be as significant as the political value per se, however, it is sufficiently noteworthy that Hillary also brings up the issue of gender inequality in the speech. Therefore, opens a new field of interpretation when Hillary utters such figurative clause.

\footnotetext{
*Author(s) Correspondence:

E-mail: dery.rovino@stkipmnc.ac.id
} 


\section{Suggested Social Knowledge}

Seemingly borrowed from corporate terminology, "the glass ceiling" is defined as the invisible boundary that distances the minority groups from gaining access to the followings: (a) higher hierarchical position; (b) better financial benefits; (c) better career; (d) better education; (d) fame; etc., while the majority group may achieve those betterments easily (Cotter, Hermsen, Ovadia, \& Vanneman, 2001; Eyring \& Stead, 1998; Frank, 2006; Wright \& Janeen Baxter, 2000). There are an array of minority groups, and yet the ones that are hotly discussed are the gender and race inequality (Cotter et al., 2001) and non-heteronormative sexual orientations (Frank, 2006). Although there has been awareness that the glass ceiling effect at the workplace can be counterproductive and detrimental to the company thus protective regulations are established in a few research contexts (Eyring \& Stead, 1998), the effect is still present in a lot of different contexts. See the following extract:

"// I / I know / I know we have still not shattered that highest and hardest glass ceiling/ but some day/ someone will/ and hopefully sooner than we might think right now.//" (line 104)

\section{'...the highest hardest glass ceiling' perhaps} may have been seen as simple as a communicative lubricant or a method to gain audience's attention. However, such clause is expressed by a woman of her caliber in a speech situated post-presidential defeat, to which it may possibly lead to a whole new world of interpretation. It sufficiently purports clear message that gender inequality must have been one of the reasons for her presidential defeat in the 2016 election. Jones (2016) defines gender as a long-standing assumption that woman and man naturally have their own roles/ assignments to which it culminates into heteronormativity (normal "duties" to the opposite sex). Also, Robert Hodge and Gunther Kress (1988) introduced a concept "logonomic system", whose principles may overlap with ideological complex, where the minority resists the stream of dominance by giving (or giving off) a category of behavior/ semiosis. In this case, furthermore, in the world of masculinity and the fact that the majority of world leaders are men (Jones, 2016), Hillary may have attempted to resist the stream of dominance - "logonomy" (Hodge \& Kress, 1988) through addressing the gender inequality issue.

Moreover, The use the subject pronoun "I" (unlike the distancing method she uses when expressing disappointments by using subject pronouns "we" and "you") and the expressive function (Searle 1969;1976, in Hatch, 1992) may suffice as an evidence of Hillary's resistance by giving off a clear-cut assumption that she takes the full responsibility of talking about gender inequality that has taken place in the election.

While she could have stopped at "but some day someone will//", the last part of the line: "[...] and hopefully sooner than we might think right now.//" may also emulate other interpretations. Because the theme of the clause is still concerning gender inequality, in general she appears to hint that another powerful figure of her kind (female) will run for president and will take over the Oval Office in the future election cycle, although she mitigates the force of the clause by utilizing the modal verb "might, which makes the sentence have less of a predictive value (Gee, 1999). Ultimately, the mitigation is bounced back with the optimism when Hillary quoted a scripture with repetitions embedded into it in order to have an impactful and inspiring closure of the speech.

121. /You know, scripture tells us / "Let us not grow weary in doing good, for in due season / we shall reap if we do not lose heart."//

122. //So my friends / let us have faith in each other /

123. / let us not grow weary /

124. / let us not lose heart /

125. / for there are more seasons to come.l

126. /And there is more work to do.//

*Author(s) Correspondence:

E-mail: dery.rovino@stkipmnc.ac.id 
All in all, although the topic is brought up and the suggestive clause in relations with gender inequality is evident, it is far from conclusive that Hillary mainly addresses the gender inequality issue given the fact that she only implicitly addresses this issue once instead of hinting it throughout the speech, unlike the speech's other social framework (politics). Nevertheless, apart from Hillary is being highly relevant to "the logonomic system" (Hodge \& Kress, 1988), Hillary's formal clothing, her pacing technique, and essentially her way of delivering speech that is signature to politicians: patriotic, proud, with powerful lexis, and minimal discourse markers "you know" (line 117-119, 120-121), may correspond to McElhinny's (1995) results of study, which concludes that women are likely to gain credibility by adapting the way they present themselves in order 'to construct a new identity relevant to their workplaces', rather than if they were to give into their feminine side (Jones, 2016). This can be a strong propensity that Hillary is somewhat conforming to the masculine-construct ideology in order to get her voice listened.

\section{DECONSTRUCTIVE INTERPRETATION}

The preferred reading of Hillary's speech is indeed to show thanks to all the people that have helped her throughout the campaign process and to provide advice to all Americans to not grow weary (123) and to not lose heart (124) in reacting to the results of the election.

However, it is shown that the combination of descriptive, representative and social interpretations appear to undermine the preferred reading to certain extent. To start, tone of disappointments is sufficiently invested in the speech due to Hillary's attempt of highlighting the supporters' feelings towards the election results //I know how disappointed you feel because / I feel it too (nod) /(line 35), using the collective pronoun "we" and our to make her position vague, and the use of unanimous subject which leads to overgeneralization, "... and so do tens of millions of Americans who invested their hopes and dreams in this effort// (line 35). She further evades the disappointment by blurring the identity of the subject by the use of determiner "this" in a few strategic areas.

Hillary brings to attention the issue of gender inequality. Through explicitly stating the presence of "the glass ceiling" implies that she has, to some extent, been victimized by both masculine-construct ideology and gender inequality. However, what is noteworthy to point out is her eloquent way of speech delivery with only a few discourse marker instances of "you know", organized and rehearsed speech pace, word choices that are strong and patriotic, seem to conform to the masculine ideology. A proposed possible explanation is that she is trying to get her message through to the world of masculinity by temporarily dismantling her femininity is deemed appropriate.

\section{FURTHER DISCUSSION}

From the previous analysis, it can be concluded that Hillary Clinton is an experienced political orator in that she portrays a figure that is calm and composed, firm yet friendly, and sufficiently eloquent with her delivery of speech. Furthermore, she does not hesitate to go off the script and then responds to her audience when snap feedback exists. Hillary further highlights her speech delivery competence by applying the uses semantic values namely parallelism, alliteration, antropomorphization, and repetition for emphasis. Such traits and nature are also common in a lot of distinguished American politicians such as Joe Biden, Barrack Obama, George W. Bush previously discussed (Reyes, 2015).

Thirty instances of personal and possessive pronouns "I" and "my" are frequent which suggest authoritativeness of speaker and identical to pronoun choices of male politicians. Furthermore, groups of phrases which suggest patriotism further enhances a level of authority embedded within Hillary Clinton's speech. On the contrary, such outcome may be overshadowed by the uses of "we" and "our" which suggest a degree of closeness between the speaker and the

\footnotetext{
*Author(s) Correspondence:

E-mail: dery.rovino@stkipmnc.ac.id
} 
audience. Additionally, Hillary sparsely refers to her family and addresses to the small donations made for her campaign, which could mean that Hillary applies identity indexing to her supporters in a way of attempting to organically establish relatable side of her and her political supporter. This is to prove that the discourse of gendered language choices where the female politicians, Hilary Clinton or Sarah Palin, embody male-like lexical derivatives are proven to be some sort of a nuance and not so clear-cut.

Looking closely, when she acknowledges Donald Trump's presidential win, there could be a marked asymmetry of power contained in her expression. See the following excerpt:

\section{3./Um (0.1) last night, I / congratulated}

Donald Trump and offered to work with him on behalf of our country.//

\section{4.//I hope that he will be a successful president for all / Americans.//}

An offer is made when there is supply for those who demand. Therefore, when she stated "[...] offered to work with him [...]", this may insinuate that Hillary is willing to provide administrative assistance for the newly-elected president. Hillary has the upper-hand. This then, in turn, bestows higher power relation on Hillary's side, despite her loss in the election (Culpeper, 2009). This seems to mimic what Palin portrays in her speech when she embeds hierarchical power over the oil companies that are about to enter her state of Alaska (Reyes, 2015).

Hillary Clinton indeed puts forth an issue of underrepresentation of female president in the USA when she uttered her disappointment for failing to break that glass ceiling. However, what is interesting here is that Hillary does not seem to gravitate her speech around gender issues. In lieu of this, Mrs. Clinton centers her speech to the USA, patriotism, and the Americans in general. If this is the case, then the gender narrative, though persists within the text, has been lowlighted by other main topics.

\section{CONCLUSION AND LIMITATION}

Foucault (1977) suggests that "A theory does not totalize; it is an instrument for multiplication and it also multiplies itself.", which becomes a point of departure of why this paper applies combination of the TACO model (O'Regan, 2006) and few other CDA principles in attempt to discover an agenda of a discourse maker, Hillary, in exploiting power over her surroundings in allotting what to highlight and to lowlight in her political statement (Cameron, 2001). The strategic moves are not explicated directly, instead, they are embedded through foregrounding and backgrounding moves, a number of rhetorical components, and significant number of patriotic and powerful lexical choices in order to conceal the disappointments. An issue of gender inequality is raised indirectly through the use of a figurative language.

This analysis, however, has never been directed to totalize the message of the discourse. The one-sidedness of the message may also be reflected from which information to be put forth. Therefore, it is imperative for the readers to be aware of the subjectivity produced in the analysis, and that there are more meanings of the text that are yet to discover. Regardless, it has been a thoughtprovoking first experience to uncover a shade of hidden meaning of a discourse sample, due to its potential for facilitating students in uncovering other possible interpretations to a text apart from its preferred reading. Being able to provide critiques and analyses is imperative for students to enhance their critical thinking, skills of cooperative work, and competences in investigating how any systems work, and generally promoting their academic skills (O’Regan, 2006).

\section{ACKNOWLEDGEMENT}

While this particular study did not receive any financial assistance, the author is eternally grateful for Kementerian Keuangan RI through Lembaga Pengelola Dana

*Author(s) Correspondence:

E-mail: dery.rovino@stkipmnc.ac.id 
Pendidikan regarding his full Master's scholarship funds, during which this study commenced.

\section{REFERENCES}

Ailes, M. J. (1991). Early medieval literature. In The Year's Work in Modern Language Studies (Vol. 53, pp. 50-67). Modern Humanities Research Association.

Binton, L. J. (2000). The Structure of Modern English: A Linguistic Introduction (Vol. 78). Philadelphia PA: John Benjamins North America. https://doi.org/10.1353/lan.2002.0164

Bourdieu, P. (1977). The economics of linguistic exchanges. Theories and Methods, 645-668.

Butler, J. (2006). Gender trouble: Feminism and the Subversion of Identity (2nd ed.). New York: Routledge Classics. https://doi.org/10.1111/1467954X.00090

Cameron, D. (2001). Working with Spoken Discourse (1st ed.). SAGE Publications.

Cotter, D. A., Hermsen, J. M., Ovadia, S., \& Vanneman, R. (2001). The Glass Ceiling Effect. Social Forces, 80(2), 655-681. Retrieved from http://www.jstor.org/stable/2675593

Culpeper, J. (2009). Politeness in Interaction. In J. Culpeper, F. Katamba, P. Kerswill, R. Wodak, \& A. McEnery (Eds.), English Language: Description, Variation, and Context (pp. 523-535). Basingstoke: Palgrave Macmillan.

Eyring, A., \& Stead, B. A. (1998). Shattering the glass ceiling: Some successful corporate practices. Journal of Business Ethics, 17(3), 245-251. https://doi.org/10.1023/A:10179868117 04

Fairclough, N. (1995). Critical Discourse Analysis: The Critical Study of Language. Language in social life series (Vol. 81). https://doi.org/10.2307/329335
Foucault, M. (1977). Intellectuals and Power. Language Counter-Memory, Practice, Selected Essays and Interviews, 139164. https://doi.org/10.2307/2905802

Frank, J. (2006). Gay glass ceilings. Economica, 73(291), 485-508. https://doi.org/10.1111/j.14680335.2006.00516.x

Gee, J. (1999). An introduction to discourse analysis: Theory and Method (1st ed.). London: Routledge, Taylor and Francis Group. https://doi.org/citeulike-articleid:310780

Gumperz, J. (1992). Contextualization and Understanding. In The Interactional Architecture of the Language Classroom: a Conversation Analysis Perspective (pp. 229-252). Oxford: Blackwell Publishing Ltd.

Han, S. (2009). Shrine, Images, and Power: The Worship of Former Worthies in Early Nineteenth Century Suzhou. T'oung Pao, Second Series, 95(1), 167195.

https://doi.org/10.1163/008254309X125 86659061406

Hatch, E. M. (1992). Speech Acts and Speech Events. In Discourse and language education: Cambridge language teaching library (pp. 121-163). Cambridge: Cambridge University Press.

Hillary Clinton's concession speech (full text). (2016). Retrieved January 12, 2017, from http://edition.cnn.com/2016/11/09/politi cs/hillary-clinton-concession-speech/

Hillary Clinton FULL Concession Speech Election 2016 [Youtube]. (2016). ABC News. Retrieved from https://www.youtube.com/watch? $\mathrm{v}=\mathrm{khK}$ 9fIgoNjQ\&t $=1155 \mathrm{~s}$

Hodge, R., \& Kress, G. (1988). Social Semiotics. New York: Cornell University Press.

*Author(s) Correspondence:

E-mail: dery.rovino@stkipmnc.ac.id 
Hyman, W. B. (2013). 'For now, hath time made me his numbering clock ': Shakespeare's Jacquemarts. Early Theatre: A Journal Associated with the Records of Early English Drama Stable, 16(2), 143-156.

Jones, L. (2016). Language and gender identities. The Routledge Handbook of Language and Identity.

Karp, J. A., \& Banducci, S. A. (2008). When politics is not just a man's game: Women's representation and political engagement. Electoral Studies, 27(1), 105-115.

https://doi.org/https://doi.org/10.1016/j. electstud.2007.11.009

Koyuncu L., B., \& Sumbas, A. (2016). Discussing women's representation in local politics in Turkey: The case of female mayorship. Women's Studies International Forum, 58, 41-50. https://doi.org/https://doi.org/10.1016/j. wsif.2016.06.003

Lanham, R. A. (1991). A Handlist of Rhetorical Terms (2nd ed.). Berkeley and Los Angeles: University of California Press. https://doi.org/10.1017/S0009840X0099 944X

Martin, J. (2010). Language , Register, and Genre. In C.Coffin, T. M. Lillis, \& K. O'Halloran (Eds.), Applied Lingusitics Methods: a reader: Systemic Functional Linguistics, Critical Discourse Analysis, and Ethnography (pp. 12-32). London: Routledge: The Open University.

Montgomery, M. (1999). Speaking sincerely: Public reactions to the death of Diana. Language and Literature, 8(1), 5-33. https://doi.org/10.1177/0963947099008 00101

Niño Murcia, M. (2003). "English is like the dollar": hard currency ideology and the status of English in Peru. World Englishes, 22(2), 121-141. https://doi.org/10.1111/1467971X.00283

O'Regan, J. P. (2006). The text as a critical object : on theorising exegetic procedure in classroom-based critical discourse analysis. In Critical Discourse Studies (Vol. 3, pp. 179-209). Routledge, Taylor and Francis Group. https://doi.org/10.1080/1740590060090 8111

Paechter, C. (2018). Rethinking the possibilities for hegemonic femininity: Exploring a Gramscian framework. Women's Studies International Forum, 68 , 121-128. https://doi.org/https://doi.org/10.1016/j. wsif.2018.03.005

Reyes, A. (2015). Building intimacy through linguistic choices, text structure and voices in political discourse. Language \& Communication, 43, 58-71. https://doi.org/10.1016/J.LANGCOM.2 015.05 .002

Rosen, J. (2017). Gender quotas for women in national politics: A comparative analysis across development thresholds. Social Science Research, 66, 82-101. https://doi.org/https://doi.org/10.1016/j.s sresearch.2017.01.008

Rovino, D. (2017). "Swipe me off my feet: the discourse of gender performances on Tinder dating app. UCL Institute of Education, London.

Sabanpan-Yu, H. (2009). NATURE AS PERSUASION : ECOLOGY IN GREMER CHAN REYES' S SHORT FICTION. In Philippine Quarterly of Culture and Society (Vol. 37, pp. 159172). University of San Carlos Publications.

Sparrow, T., \& Hutchinson, A. (2013). A History of Habit: from Aristotle to Bourdieu. A History of Habit: From Aristotle to Bourdieu. Lanham: Lexington Books.

Spicer, Z., McGregor, M., \& Alcantara, C. (2017). Political opportunity structures and the representation of women and visible minorities in municipal elections. Electoral Studies, 48, 10-18. https://doi.org/https://doi.org/10.1016/j. electstud.2017.01.002

Van Dijk, T. A. (2008). Discourse and Power (1st ed.). New York: Palgrave Macmillan.

*Author(s) Correspondence:

E-mail: dery.rovino@stkipmnc.ac.id 
https://doi.org/10.1111/j.1467-

9841.2010.00443 6.x

Wallace, C. (2003). Critical Reading in Language Education. New York: Palgrave Macmillan. https://doi.org/10.1057/9780230514447

Watling, J., Cargill, M., Green, I., Adams, R., \& Andrew Hall. (2007). A d TAT: The Adelaide Text Analysis Tool (Concordancing Software). Australia. Retrieved from http://www.adelaide.edu.au/carst/resour ces-tools/adtat/

Wright, E. O., \& Janeen Baxter. (2000). The Glass Ceiling Hypothesis : A Reply to Critics. In Gender and Society (Vol. 14, pp. 814-821). Sage Publications Inc. Retrieved from http://www.jstor.org/stable/190377

*Author(s) Correspondence:

E-mail: dery.rovino@stkipmnc.ac.id 